\title{
TINGKAT PENERIMAAN E-COMMERCE AGRIBISNIS OLEH IBU RUMAH TANGGA DI KELURAHAN SUMUR BATU, KECAMATAN BANTAR GEBANG, KOTA BEKASI
}

\section{LEVEL OF AGRIBUSINESS ACCEPTANCE E-COMMERCE BY HOUSEHOLD MOTHER IN KELURAHAN SUMUR BATU, KECAMATAN BANTAR GEBANG, BEKASI}

\author{
Siti Aulia Rahmaniah \\ Universitas Padjajaran \\ Email: sitiaulia.rahmaniah985@gmail.com
}

\begin{abstract}
ABSTRAK
E-commerce di Indonesia sudah semakin berkembang, tidak menutup kemungkinan bahwa sektor pertanian turut serta dalam digitalisasi bisnis tersebut, salah satunya dengan keberadaan e-commerce agribisnis yang saat ini sudah mulai berkembang sejak adanya program pemerintah tentang sinergi aksi untuk ekonomi rakyat pada tahun 2015. Penelitian ini dilakukan untuk mengetahui tingkat penerimaan ibu rumah tangga dalam menerima ecommerce agribisnis dengan menerapkan model UTAUT (Unified Theory of Acceptance and Use of Technology). Metode penelitian yang digunakan kuantitatif dengan teknik analisis data menggunakan PLS (Partial Least Square). Responden penelitian sebanyak 99 ibu rumah tangga Kelurahan Sumur Batu, Kecamatan Bantar Gebang, Kota Bekasi. Teknik penentuan responden menggunakan simple random sampling. Hasil penelitian menunjukkan bahwa tingkat penerimaan e-commerce agribisnis oleh ibu rumah tangga di Kelurahan Sumur Batu masih rendah namun bisa memberikan sikap positif dan menunjukkan ketertarikan. Faktor yang paling memengaruhi tingkat penerimaan e-commerce agribisnis oleh ibu rumah tangga di Kelurahan Sumur Batu ialah kondisi pemfasilitasi sebesar 36,7\%. Sedangkan variabel Ekspektansi Usaha tidak memiliki pengaruh yang signifikan namun berpengaruh positif terhadap minat penggunaan.
\end{abstract}

Kata Kunci: Model UTAUT, PLS, E-commerce Agribisnis, Tingkat Penerimaan.

\section{ABSTRACT}

Hal. $27-40$

Jurnal Perilaku Dan Strategi Bisnis

Vol.8 No. 1, 2020

E-commerce in Indonesia has increasingly developed, it does not rule out the possibility of the agricultural sector to participate in digitizing this business, one of it is by considering agribusiness e-commerce which has now begun to develop since the government program on synergy of action for the people's economy in 2015. This research was done to determine the level of acceptance of housewives in accepting agribusiness ecommerce using the UTAUT (The Unification of Acceptance and Technology Use Theory) model. Quantitativ methode is used in this research with PLS (Partial Least Square) as the data analysis technique. The respondents in this research were 99 housewives in Sumur Batu Village, Bantar Gebang District, Bekasi City. Simple random sampling is used to 
determine the respondents. The results showed that the level of acceptance of agribusiness e-commerce by housewives in Sumur Batu Village is still low but can provide a positive attitude and show interest. The factor that most influenced the level of acceptance of agribusiness e-commerce by housewives in the Sumur Batu Village was the facilitating condition of $36.7 \%$. While the Business Expectancy variable does not have a significant effect but positively influences the use interest.

\section{Keywords: UTAUT Model, PLS, Agribusiness E-commerce, Acceptance Level.}

\section{PENDAHULUAN}

Indonesia telah memasuki era revolusi industri 4.0. Dengan semakin berkembangnya teknologi, termasuk teknologi informasi dan komunikasi atau lebih dikenal dengan Information and Communication Technology (ICT) berdampak kepada semakin berkembang pula internet, termasuk pada bidang bisnis dan perdagangan. Salah satu penerapan ICT dalam kegiatan pemasaran dan penjualan adalah dengan adanya electronic commerce (ecommerce). Dalam lingkup Asia Tenggara, pada tahun 2016 Indonesia memimpin kegiatan perdagangan melalui platform online atau e-commerce dengan penjualan sebesar 5,29 juta US Dollar (eMarketer, 2016).

Salah satu sektor ekonomi yang sudah menerapkan e-commerce dalam proses pemasarannya adalah sektor pertanian atau agribisnis. E-commerce agribisnis mulai berkembang di beberapa negara seperti Cina dan Amerika. Sebanyak 6000 platform ecommerce agribisnis sudah berkembang di Cina dan berhasil untuk memotong rantai pasok dan menghubungkan petani kecil dengan konsumen menurut (Liu et al.,2013), di Amerika Serikat sebanyak 4000 platform e-commerce agribisnis sudah berkembang dan akses kepada produk agribisnis dan peternakan meningkat sebesar $65 \%$, sebanyak lebih dari 85.000 pengguna teknologi mengakses e-commerce agribisnis setiap bulannya (Zapata et al., 2013). Perkembangan e-commerce agribisnis di Indonesia mulai berkembang ketika pemerintah mengadakan Program Sinergi Aksi Untuk Ekonomi Rakyat pada tahun 2015. Beberapa Platform e-commerce agribisnis yang saat ini berkembang yaitu sayurbox, tanihub, limakilo, etanee, eragano, sikumis dan e-commerce agribisnis lainnya.

Salah satu kota di Jawa Barat yang mendukung peningkatan perekonomian berbasis potensial jasa kreatif dan berdaya saing adalah Kota Bekasi. Kota Bekasi memiliki visi "Cerdas, Kreatif, Maju, Sejahtera, dan Ihsan" dengan salah satu misinya yaitu meningkatkan perekonomian dengan pengelolaan rantai pasok produk pertanian melalui digital untuk stabilisasi pasokan dan harga barang pangan. Saat ini, e-commerce agribisnis yang menyentuh pangsa pasar Kota Bekasi ialah Tanihub dan Sayurbox, kedua e-commerce ini baru mengantarkan pesanan ke Kota Bekasi dan Kota Depok untuk wilayah Jawa Barat.

Berbanding terbalik dengan perkembangan e-commerce agribisnis yang semakin meningkat, Asosiasi Pengelola Pusat Perbelanjaan (APPBI) mencatat bahwa pada tahun 2018, masyarakat yang berbelanja secara online baru sekitar 40 persen.

Salah satu kecamatan di Kota Bekasi yang memiliki tingkat pertanian tertinggi dan berpotensi dalam mendukung visi dan misi Kota Bekasi adalah Kecamatan Bantar Gebang. Kecamatan Bantar Gebang memiliki luas tanah sawah tadah hujan tertinggi dibandingkan kecamatan lainnya yaitu seluas 223 ha. Hal tersebut dapat menjadi potensi bagi wilayah setempat dalam membantu memasarkan produk pertanian melalui e-commerce agribisnis baik sebagai mitra kerja maupun mengadopsi sistem yang telah dijalankan oleh sayurbox atau tanihub. Potensi pengembangan tersebut tidak didukung oleh pernyataan yang diungkapkan oleh salah satu staff Kecamatan Bantar Gebang yang menyatakan bahwa ibu rumah tangga di Kecamatan Bantar Gebang belum seluruhnya mengadopsi e-commerce agribisnis dalam berbelanja buah dan sayur, padahal calon konsumen di Kecamatan Bantar Gebang cukup banyak yaitu ibu rumah tangga khususnya yang telah mengadopsi teknologi dan internet. 
Salah satu Kecamatan di Bantar Gebang yang menjadi potensi pasar bagi perusahaan e-commerce agribisnis adalah Kelurahan Sumur Batu yang memiliki jumlah rumah tangga tertinggi, namun pada kenyataannya belum banyak ibu rumah tangga yang mengetahui dan menggunakan e-commerce agribisnis walaupun telah ter akses oleh internet. Keberadaan e-commerce agribisnis yang terhitung baru di Indonesia juga masih memiliki banyak evaluasi dalam pelaksanaannya, salah satunya adalah kepercayaan konsumen terhadap produk yang diterima, seperti proses pengiriman, pengemasan dan lamanya waktu yang dibutuhkan dalam pengiriman. Faktor yang memengaruhi agar calon konsumen percaya dan bisa menerima terhadap inovasi ialah ekspektansi kinerja, ekspentansi usaha, pengaruh sosial, dan keadaan yang memfasilitasi sesuai dengan model Unified Theory of Acceptance and Use of Technology yang diteliti oleh Venkatesh (2003). Penelitian ini bertujuan untuk mengkaji tingkat penerimaan e-commerce agribisnis oleh ibu rumah tangga menggunakan model UTAUT sehingga dapat diketahui faktor apa saja yang perlu ditingkatan. Berdasarkan latar belakang yang sudah diuraikan, penulis tertarik untuk melakukan penelitian yang berjudul "Tingkat Penerimaan E-Commerce Agribisnis oleh Ibu Rumah Tangga di Kelurahan Sumur Batu, Kecamatan Bantar Gebang, Kota Bekasi"

\section{METODE PENELITIAN}

\section{Objek, Subjek dan Tempat Penelitian}

Penelitian ini mengkaji tentang tingkat penerimaan e-commerce agribisnis oleh ibu rumah tangga. Objek pada penelitian ini adalah tingkat penerimaan (acceptance), sedangkan subjek pada penelitian ini ibu rumah tangga di Kelurahan Sumur Batu, Kecamatan Bantar Gebang, Kota Bekasi. Lokasi penelitian berada di Kelurahan Sumur Batu, Kecamatan Bantar Gebang, Kota Bekasi. Pemilihan lokasi dipilih dengan pertimbangan bahwa Kota Bekasi memiliki misi tentang pemotongan rantai pasok menggunakan digital, Kecamatan Bantar Gebang dipilih dengan pertimbangan bahwa Kecamatan tersebut memiliki lahan pertanian terbesar di Kota Bekasi sekaligus dengan alasan kecamatan tersebut masih di daerah perkotaan dan letaknya di pinggir kota. Pemilihan lokasi kelurahan dengan dasar pertimbangan bahwa di kelurahan tersebut memiliki jumlah rumah tangga tertinggi.

\section{Desain dan Teknik Penelitian}

Desain penelitian yang dilakukan merupakan penelitian kuantitatif dengan Teknik penelitian survey. Pengambilan data menggunakan kuesioner sebagai data primer.

\section{Cara Penentuan Responden}

Sebelum ditentukan jumlah sampel, maka terlebih dahulu dilakukan cluster sampling masyarakat Kota Bekasi sesuai dengan karakteristik tujuan penelitian. Berdasarkan data yang didapat melalui Badan Pusat Statistik Kota Bekasi, dapat diketahui bahwa jumlah populasi rumah tangga di Kelurahan Sumur Batu sebanyak 7.163 rumah tangga yang tersebar dalam 11 rukun warga (Tabel 1 ).

Tabel 1. Jumlah Rumah Tangga, Rukun Tetangga, dan Rukun Warga di Kecamatan Bantar Gebang,

\begin{tabular}{lllll}
\hline No. & Kelurahan & Rumah Tangga & Rukun Tetangga & Rukun Warga \\
\hline 1 & Ciketing Udik & 6.300 & 46 & 9 \\
$\mathbf{2}$ & Sumur Batu & $\mathbf{7 . 1 6 3}$ & $\mathbf{7 3}$ & $\mathbf{1 1}$ \\
3 & Cikiwul & 6.296 & 32 & 7 \\
4 & Bantar Gebang & 6.882 & 31 & 10 \\
\hline & Jumlah & 26.641 & 182 & 37 \\
\hline
\end{tabular}

Sumber: Arsip Kelurahan Sumur Batu, Kecamatan Bantar Gebang, Kota Bekasi, 2017. 
Teknik yang digunakan untuk menentukan pengambilan sampel menggunakan Teknik simple random sampling dan dihitung menggunakan rumus slovin. Jumlah sampel yang diambil dalam penelitian ini sebanyak 98,6 ibu rumah tangga yang kemudian dibulatkan menjadi 99 responden.

\section{Teknik Analisis Data}

Analisis Statistik Deskriptif

Menurut Sugiyono (2014) statistik yang digunakan untuk menganalisis sebuah data melalui deskripsi atau menggambarkan berdasarkan data yang telah dikumpulkan tanpa bermaksud untuk membuat sebuah kesimpulan atau generalisasi. Analisis deskriptif digunakan dengan menggunakan table frekuensi distribusi untuk mengetahui skor variabel penelitian yang meliputi sangat tidak setuju, tidak setuju, cukup setuju, setuju, dan sangat tidak setuju. Skor maksimum setiap kuesioner adalah 5 dan skor minum adalah 1 . Berikut ini merupakan tabel penggambaran skor dengan menggunakan skala likert:

Tabel 2. Skor Alternatif Jawaban Kuesioner

\begin{tabular}{ll}
\hline Alternatif Jawaban & Skor \\
\hline Sangat Setuju & 5 \\
Setuju & 4 \\
Cukup Setuju & 3 \\
Tidak Setuju & 2 \\
Sangat Tidak Setuju & 1 \\
\hline
\end{tabular}

\section{Uji Validitas}

Uji validitas adalah pengujian untuk mengukur apakah sebuah instrumen yang digunakan menunjukkan kevalidan atau kesahihan (Sugiyono, 2008). Uji validitas dilakukan sebelum pengolahan data ketika jawaban dari kuesioner yng disebar sudah terkumpul. Pengujian validitas tiap butir kuesioner dilakukan pada program SPSS dengan menggunakan Pearson correlation coefficient ( $r$ hitung). Menurut Azwar (1999), nilai $r$ hitung menjadi dasar pengambilan keputusan dengan ketetapan sebagai berikut:

Jika nilai $r$ hitung $\geq r$ tabel, maka instrument dinyatakan valid Jika nilai $r$ hitung $\leq r$ tabel, maka instrument dinyatakan tidak valid

Nilai $r$ tabel didasarkan pada angka derajat kebebasan (degree of freedom). Derajat kebebasan diartikan sebagai jumlah sampel $(\mathrm{N})$ dikurangi banyaknya kendali bebas atau pembatasan atas pengamatan. Angka degree of freedom didapatkan dari jumlah sampel dikurangi $2(d f=\mathrm{N}-2)$. Berdasarkan perhitungan menggunakan rumus slovin, jumlah responden yang ideal dengan tingkat kekeliruan $10 \%$ adalah sebanyak 99 responden, sehingga dapat diketahui nilai degree of freedom (df) sebesar 97. Dengan tingkat kekeliruan sebesar $10 \%$ atau 0,1 , maka dapat diketahui nilai $r$ tabel $=0.1663$.

Pengujian statistik mengacu pada kriteria:

$\begin{array}{ll}\mathrm{N} & =99 \\ \mathrm{a} & =10 \% \\ \text { rtabel } & =0.1663 \\ r \text { hitung } \geq r \text { tabel } & =\text { valid } \\ r \text { hitung } \leq r \text { tabel } & =\text { tidak valid }\end{array}$

\section{Uji Realibilitas}

Menurut Arikunto (2001), uji realibilitas merupakan tingkat keakuratan sebuah instrumen dapat digunakan dan diandalkan. Uji realibilitas dilakukan dengan tujuan 
mengetahui apakah sebuah instrumen dapat konsisten menghasilkan data yang sama jika telah digunakan berulang-ulang. Dalam penelitian ini, uji realibilitas dilakukan menggunakan rumus Cronbach's alpha. Menurut Noor (2014), terdapat hal-hal pokok yang perlu diketahui dalam sebuah uji realibilitas yaitu uji realibilitas perlu dilakukan bersamaan terhadap seluruh pertanyaan, dan sebuah instrument dikatakan reliabel ketika nilai croanbach's alpha $>0.60$.

\section{Alat Analisis}

Partial Least Square digunakan sebagai alat analisis dalam penelitian ini. Ketika data sudah didapatkan, maka langkah selanjutnya yaitu mengolah dan menganalisis data menggunakan software smartPLS 3.0 sebagai berikut:

1. Perancangan Model Struktur (Inner Model)

Inner model menggambarkan sebuah hubungan konstruk laten berdasarkan teori. Perancangan inner mode/ didasarkan pada rumusan masalah dan hipotesis penelitian.

2. Perancangan Model Pengukuran (Outer Model)

Outer Mode/ menggambarkan bagaimana setiap blok indikator saling berkaitan dengan konstruk latennya. Perancangan outer model akan menentukan sifat indikator dari masing-masing konstruk laten. Pada penelitian ini, sifat indikator dari masing-masing konstruk penelitian adalah refleksif.

3. Evaluasi Model

\section{a) Evaluasi Outer Model}

Evaluasi outer model dilakukan untuk memastikan bahwa measurement yang digunakan layak untuk dijadikan pengukuran (valid dan reliabel). Dalam menilai evaluasi outer model menggunakan tiga kriteria yaitu, Convergent Validity, Discriminant Validity, Composite Reliability.

Convergent Validity dari model pengukuran dengan sifat indikator refleksif dinilai berdasarkan korelasi antara skor item yang dihitung dengan menggunakan PLS. Ghozali (2006) mengatakan bahwa pada penelitian tahap awal, nilai loading 0,5 sampai 0,6 dianggap cukup memadai. Ukuran refleksif dikatakan tinggi jika berkorelasi lebih dari 0,70 dengan konstruk yang diukur.

Discriminant Validity dengan sifat indikator refleksif dinilai dengan melihat output cross loading pengukuran. Metode penentuan discriminant validity yang digunakan dalam penelitian ini adalah dengan membandingkan nilai Average Variance Extacted $(\sqrt{A V E})$ setiap konstruk dengan nilai korelasi antar konstruk lainnya (Latent Variable Correlation).

Composite Reliability dievaluasi menggunakan hasil yang diberikan PLS. Rumus Composite Reliability sebagai berikut:

$$
\rho c=\frac{\left(\sum \lambda_{i}^{2}\right)}{\left(\sum \lambda_{i}^{2}\right)+\sum_{i} \operatorname{var}\left(\varepsilon_{i}\right)}
$$

Dibandingkan menggunakan croanbach's alpha, ukuran ini merupakan closer approximation dengan asumsi estimasi parameter adalah kuat sedangkan croanbach alpha cenderung lower bound estimate reliability. $\rho c$ sebagai ukuran internal konsistensi hanya dapat digunkan untuk sifat indikator refleksi (Ghozali, 2006).

\section{b) Evaluasi Inner Model}

Evaluasi inner model dilakukan untuk meyakinkan bahwa model struktural yang dikonstruk adalah robust dan kuat. Pengujian inner model menggunakan PLS diawali dengan melihat nilai R-square untuk setiap variable laten dependen. Penilaian perubahan $\mathrm{R}$-Square bertujuan untuk mengetahui pengaruh substantive variabel laten independent terhadap variable laten dependen. 


\section{c) Pengujian Hipotesis (Resampling Bootsraping)}

Uji hipotesis antar konstruk dianalisis dengan menggunakan metode resampling bootstrap yang dikembangkan oleh Geisser (Ghozali, 2006). Statistik yang digunakan dalam pengujian ini yaitu uji t. Penggunaan metode resampling dalam penelitian ini dapat memberikan kemungkinan bahwa data yang digunakan dapat terdistribusi secara bebas, tidak membutuhkan asumsi distribusi secara normal, dan tidak membutuhkan sampel yang besar. Uji $\mathrm{t}$ bertujuan untuk mengetahui apakah variabel indepen berpengaruh terhadap variabel dependen.

Pengujian hipotesis dilakukan dengan melihat hasil dari resampling bootstrap dengan menggunakan software smartPLS 3.0. Hipotesis yang diajukan dalam penelitian ini yaitu:

Ho (hipotesis nihil) : $\mathrm{Y}_{1}=0$; artinya tidak ada pengaruh antara variabel independent terhadap variabel dependen.

Ha (Hipotesis alternative) $: \gamma_{1} \neq 0$; artinya terdapat pengaruh antara variabel independent terhadap variabel dependen.

\section{HASIL DAN PEMBAHASAN}

\section{Gambaran Umum Tempat Penelitian}

Kelurahan Sumur Batu berada di Kecamatan Bantar Gebang, Kota Bekasi, Jawa Barat. Kelurahan ini terbentuk pada tanggal 19 April 2002. Kelurahan Sumur Batu merupakan salah satu kelurahan dari delapan kelurahan yang ada di Kecamatan Bantar Gebang yang wilayahnya dikhususkan sebagai pusat agribisnis dan daerah resapan air. Luas Kelurahan Sumur Batu $\pm 568,955$ ha dengan \pm 318 ha diperuntukkan sebagai pemukiman penduduk dan sisanya digunakan sebagai tempat pembuangan akhir (TPA) Pemda DKI Jakarta seluas kurang lebih 20 ha dan Kota Bekasi kurang lebih $\pm 17,2$ ha, dan juga dijadikan sebagai sarana gedung perkantoran, dan sarana pendidikan. Keberadaan TPA Bantar Gebang memiliki dampak tersendiri bagi masyarakat sekitar. Para pemulung yang datang dari luar daerah untuk mengais rejeki, penduduk pribumi, pun pada akhirnya ikut mengumpulkan sampah-sampah plastik untuk dijual kembali dalam menghidupi kebutuhan sehari-hari. Selain itu, akibat dari keberadaan TPA ini, warga sekitar yang terkena dampak pun diberikan kompensasi atau ganti rugi akan ketidaknyamanan hal tersebut.

\section{Deskripsi Hasil Penelitan}

Informasi yang didapatkan dari lapangan yang terkait dengan profil ibu rumah tangga, meliputi: usia, pendidikan, pengalaman dalam berbelanja online (agribisnis maupun non-agribisnis), pendapat mengenai e-commerce agribisnis, dan tingkat penerimaan $e$ commerce agribisnis.

\section{Deskripsi Karakteristik Ibu Rumah Tangga}

1. Usia

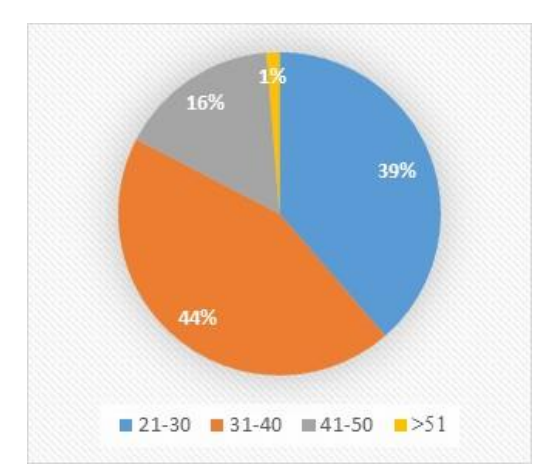

Gambar 1. Diagram Lingkaran Tingkat Usia Responden 
Berdasarkan data yang didapatkan di lapangan dan telah dibuat diagram lingkaran (Gambar 2), dapat diketahui bahwa mayoritas responden berusia 31-40 tahun yaitu sebanyak 41 responden (44\%). Berdasarkan hasil survey di lapangan, penulis mengobservasi bahwa rentang usia yang bisa menerima inovasi e-commerce agribisnis yaitu usia 21-40 tahun, Arning \& Ziefle (2007), Venkatesh \& Morris (2000) mengatakan bahwa usia memiliki peran yang penting dalam penerimaan sebuah teknologi.

2. Tingkat Pendidikan

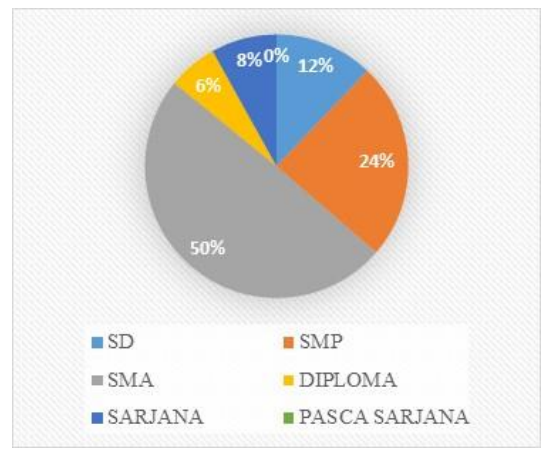

Gambar 2. Diagram Lingkaran Tingkat Pendidikan Terakhir Responden

Berdasarkan data yang didapatkan di lapangan dan telah dibuat diagram lingkaran (Gambar 3), dapat diketahui bahwa setengah dari responden memiliki tingkat pendidikan tamat SLTA sebanyak 49 responden (50\%), diikuti dengan responden tamat SLTP sebanyak 24 responden (24\%). Data tersebut menjelaskan bahwa mayoritas ibu rumah tangga di Kelurahan Sumur Batu, Kecamatan Bantar Gebang belum memiliki tingkat Pendidikan yang tinggi. Pada saat melakukan survey di lapangan, penulis mengobservasi bahwa semakin tinggi pendidikan seseorang berpengaruh terhadap kemudahan menerima inovasi baru, namun tidak menutup kemungkinan bahwa individu dengan Pendidikan rendah tidak bisa menerima inovasi, hal tersebut tergantung kepada masing-masing motivasi individu tersebut.

3. Pengalaman Berbelanja Secara Online

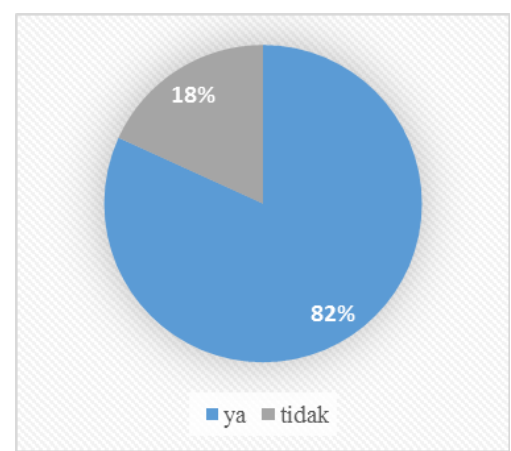

Gambar 3. Diagram Lingkaran Berbelanja Online

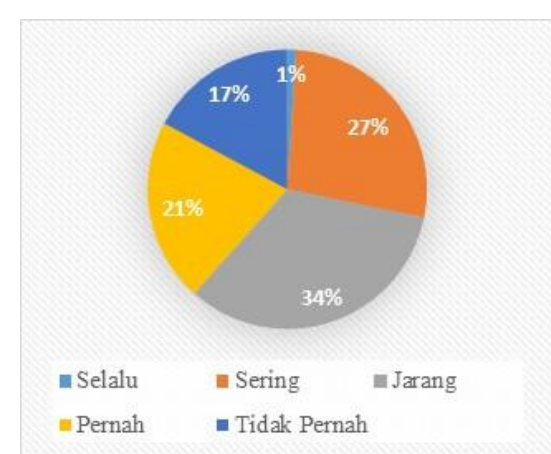

Gambar 4. Diagram Lingkaran Pengalaman dalam Berbelaja Online

Berdasarkan data yang didapatkan di lapangan dan telah dibuat diagram lingkaran (Gambar 4 dan Gambar 5), dapat diketahui bahwa mayoritas responden pernah berbelanja secara online sebanyak 81 responden (82\%) dengan frekuensi jarang sebanyak 33 responden (34\%). Data tersebut menjelaskan bahwa mayoritas responden ibu rumah tangga di Kelurahan Sumur Batu sudah mengenal teknologi, internet dan juga paham cara menggunakan sistem e-commerce.

4. Pengetahuan Mengenai E-Commerce Agribisnis 


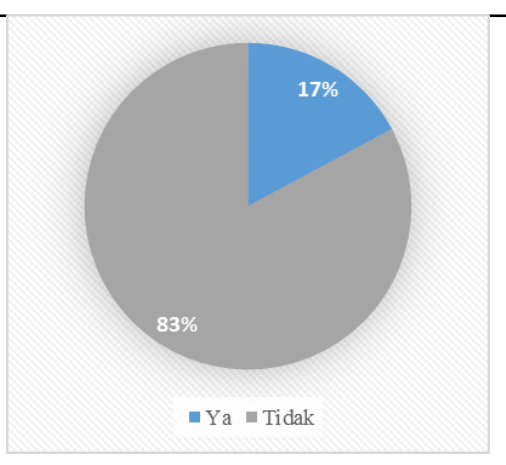

Gambar 5. Pengetahuan Responden terhadap E-Commerce Agribisnis

Berdasarkan hasil penelitian di lapangan, sebanyak $83 \%$ responden masih belum sadar atau aware akan keberadaan e-commerce agribisnis. Data tersebut jika dibandingkan dengan data sebelumnya menggambarkan bahwa ibu rumah tangga sudah mengadopsi internet dan e-commerce dalam kehidupan sehari-hari untuk berbelanja, namun masih belum mengadopsi untuk berbelanja produk pertanian.

\section{Deskripsi Stastistik Konstruk}

Tabel 3. Statistik Deskriptif Konstruk

\begin{tabular}{lrrrrrr}
\hline & N & Minimum & Maximum & Sum & Mean & Std. Deviation \\
\hline Performance Expectancy (PE) & 99 & 10 & 23 & 1652 & 16.69 & 3.142 \\
Effort Expectancy (EE) & 99 & 6 & 14 & 943 & 9.53 & 1.402 \\
Social Influence (SI) & 99 & 4 & 14 & 814 & 8.22 & 2.102 \\
Facilitating Conditions (FC) & 99 & 7 & 19 & 1255 & 12.68 & 2.766 \\
Behavioral Intention (BI) & 99 & 6 & 12 & 905 & 9.14 & 2.015 \\
Valid N (listwise) & 99 & & & & & \\
\hline
\end{tabular}

\section{Konstruk PE (Performance Expectancy)}

Data konstruk PE didapatkan dari penyebaran kuesioner dengan jumlah pernyataan sebanyak 5 buah menggunakan skala pilihan jawaban 1-5 (5 alternatif jawaban), skor empirik menyebar dari skor minimum 10 dan maksimum 23, dengan total 1652, rata-rata 16,69, dan simpangan baku 3,142.

2. Konstruk EE (Effort Expectancy)

Data konstruk EE didapatkan dari penyebaran kuesioner dengan jumlah pernyataan sebanyak 3 buah menggunakan skala pilihan jawaban 1-5 (5 alternatif jawaban), skor empirik menyebar dari skor minimum 6 dan maksimum 14, dengan total 943, rata-rata 9,53, dan simpangan baku 1,402.

3. Konstruk SI (Social Influence)

Data konstruk SI didapatkan dari penyebaran kuesioner dengan jumlah pernyataan sebanyak 3 buah menggunakan skala pilihan jawaban 1-5 (5 alternatif jawaban), skor empiric menyebar dari skor minimum 4 dan maksimum 14, dengan total 814, rata-rata 8,22, dan simpangan baku 2,102.

4. Konstruk FC (Facilitating Condition)

Data konstruk FC didapatkan dari penyebaran kuesioner dengan jumlah pernyataan sebanyak 4 item menggunakan skala pilihan jawaban 1-5 (5 alternatif jawaban), skor empirik menyebar dari skor minimum 7 dan maksimum 19, dengan total 1255, rata-rata 12,68, dan simpangan baku 2,766.

5. Konstruk BI

Data konstruk BI didapatkan dari penyebaran kuesioner dengan jumlah pernyataan sebanyak 3 item dengan skala pilihan jawaban 1-5 (5 alternatif jawaban), skor empirik menyebar dari skor minimum 6 dan maksimum 12, dengan total 905, rata-rata 9,14, dan simpangan baku 2,015. 
Analisis Pengaruh Tingkat Penerimaan terhadap Minat Pemanfaatan

1. Estimasi Model

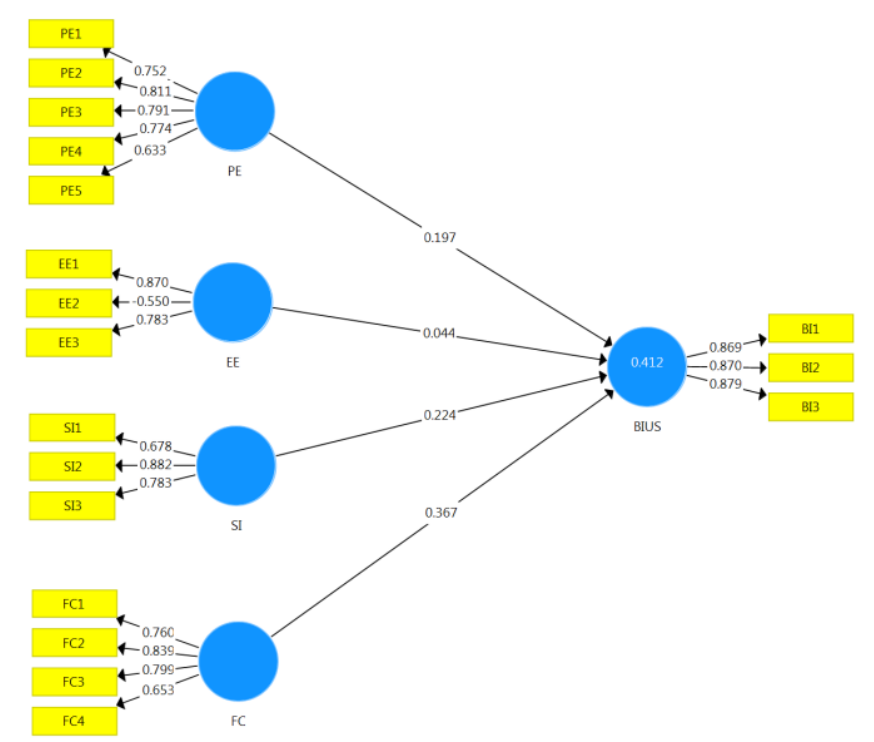

Gambar 6. Hasil Estimasi Model

Berdasarkan estimasi model di atas yang telah dibuat menggunakan software SmartPLS 3.0. Dapat diketahui bahwa nilai loading factor dari masing-masing indikator sudah di atas 0,5. Hal tersebut menyatakan bahwa model selanjutnya dapat di evaluasi, (Chin, 1998).

Tabel 4. Output Outer Loadings

\begin{tabular}{|c|c|c|c|c|c|}
\hline \multicolumn{6}{|c|}{ Outer Loadings } \\
\hline & BIUS & EE & FC & PE & SI \\
\hline BI1 & 0.896 & & & & \\
\hline BI2 & 0.870 & & & & \\
\hline BI3 & 0.879 & & & & \\
\hline EE1 & & 0.870 & & & \\
\hline EE2 & & -0.550 & & & \\
\hline EE3 & & 0.783 & & & \\
\hline FC1 & & & 0.760 & & \\
\hline FC2 & & & 0.839 & & \\
\hline FC3 & & & 0.799 & & \\
\hline FC4 & & & 0.653 & & \\
\hline PE1 & & & & 0.752 & \\
\hline PE2 & & & & 0.811 & \\
\hline PE3 & & & & 0.791 & \\
\hline PE4 & & & & 0.774 & \\
\hline PE5 & & & & 0.663 & \\
\hline SI1 & & & & & 0.678 \\
\hline SI2 & & & & & 0.882 \\
\hline SI3 & & & & & 0.783 \\
\hline
\end{tabular}


Berdasarkan output outer loadings (Tabel 5) dapat dilihat bahwa nilai outer loadings masing-masing indikator terhadap konstruk sudah memenuhi kriteria convergent validity karena memiliki nilai >0,5 namun Indikator effort expectancy 2 (EE 2) belum memenuhi kriteria convergent validity dikarenakan memiliki nilai $-0,550$ yang artinya indikator memiliki logika yang berbanding terbalik.

Discriminant validity dapat dianalisis dengan melihat perbandingan nilai akar kuadrat dari average variance extracted $(\sqrt{\mathrm{AVE}})$ setiap konstruk dengan nilai korelasi antara konstruk (latent variable correlation).

Tabel 5. Output Average Variance Extracted

\begin{tabular}{lcc}
\hline & Average Variance Extracted $($ AVE) & Akar AVE $(\sqrt{\text { AVE }})$ \\
\hline BIUS & 0.761 & 0.872 \\
EE & 0.557 & 0.746 \\
FC & 0.587 & 0.766 \\
PE & 0.570 & 0.754 \\
SI & 0.617 & 0.785 \\
\hline
\end{tabular}

Tabel 6. Output Latent Variable Correlation

\begin{tabular}{llllll}
\hline \multicolumn{5}{c}{ Latent Variable Correlation } & \\
\hline & BIUS & EE & FC & PE & SI \\
BIUS & 1.000 & & & & \\
EE & 0.379 & 1.000 & & & \\
FC & 0.537 & 0.424 & 1.000 & & \\
PE & 0.478 & 0.483 & 0.390 & 1.000 & 1.000 \\
SI & 0.465 & 0.376 & 0.331 & 0.520 & \\
\hline
\end{tabular}

Berdasarkan Tabel 6 dan 7, dapat diketahui bahwa model telah memiliki nilai discriminant validity yang memadai, hal tersebut dapat dilihat dari nilai akar AVE untuk masing-masing konstruk lebih tinggi daripada nilai latent variable correlation. Contohnya pada nilai akar AVE konstruk PE sebesar 0,754 lebih tinggi dari nilai latent variable correlation PE dengan BIUS sebesar 0,478 , lebih tinggi dari nilai korelasi PE dengan EE sebesar 0,483, lebih tinggi dari nilai korelasi PE dengan FC sebesar 0,390.

composite reliability dilihat dengan memperhatikan nilai croanbach's alpha. Konstruk dapat dikatakan reliabel apabila memiliki nilai composite reliability dan croanbach's alpha di atas 0,70 (Ghozali,2006).

Tabel 7. Output Construct Reliability

\begin{tabular}{lcc}
\hline \multicolumn{3}{c}{ Construct Reliability } \\
\hline BIUS & Croanbach's Alpha & Composite Reliability \\
EE & 0.843 & 0.905 \\
FC & -0.007 & 0.478 \\
PE & 0.763 & 0.849 \\
SI & 0.810 & 0.868 \\
\hline
\end{tabular}

Berdasarkan tabel 8, dapat diketahui bahwa masing-masing konstruk telah memiliki reliabilitas yang baik karena memiliki nilai croanbach's alpha dan nilai composite reliability di atas 0,7 kecuali untuk konstruk effort expectancy (EE) dinyatakan tidak reliabel karena memiliki nilai croanbach's alpha dan nilai composite reliability dibawah 0,7 yaitu sebesar 0,007 dan 0,478 .

\section{Pengujian Inner Model}


pengujian terhadap inner model dengan memperhatikan nilai $R$-square $\left(R^{2}\right)$ pada konstruk endogen. Menurut (Ghozali,2006), mengatakan bahwa model yang memiliki nilai $R$ square sebesar 0,67 mengindikasikan bahwa model "baik", nilai $R$-square sebesar 0,33 mengindikasikan bahwa model "moderat", nilai $R$-square sebesar 0,19 mengindikasikan bahwa model "lemah".

Tabel 8. Output Nilai R-Square

\begin{tabular}{ll}
\hline & $\boldsymbol{R}$-Square $\left(\boldsymbol{R}^{2}\right)$ \\
\hline BIUS & 0,412 \\
EE & \\
FC & \\
PE & \\
SI & \\
\hline
\end{tabular}

Berdasarkan tabel output $R$-square $\left(R^{2}\right)$ di atas menunjukkan bahwa nilai $R$-square behavioral intention adalah sebesar 0,412 (41,2\%). Hal tersebut mengartikan bahwa kemampuan konstruk eksogen (variabel independen) dalam menjelaskan konstruk endogen (variabel dependen) behavioral intention dapat dikatakan moderat atau dapat pula diartikan bahwa kosntruk EE, FC, PE, SI hanya dapat menjelaskan sebesar 41,2\% dan sisanya diartikan melalui variabel lain di luar model yang digunakan.

Tabel 9. Output Path Coefficient

\begin{tabular}{llllll}
\hline & \multicolumn{5}{c}{ Path Coefficient } \\
\hline & Original Sample & Sample Mean & Standard Deviation & T Statistics & P Values \\
PE -> BIUS & 0.197 & 0.201 & 0.117 & $\mathbf{1 . 6 8 6}$ & 0.092 \\
EE -> BIUS & 0.044 & 0.057 & 0.088 & $\mathbf{0 . 5 0 6}$ & 0.613 \\
SI -> BIUS & 0.224 & 0.225 & 0.099 & $\mathbf{2 . 2 6 2}$ & 0.024 \\
FC -> BIUS & 0.367 & 0.367 & 0.077 & $\mathbf{4 . 7 6 6}$ & 0.000 \\
\hline
\end{tabular}

Pengujian Hipotesis

Pengujian hipotesis antara konstruk eksogen dengan konstruk endogen digunakan dengan menggunakan metode resampling bootstrap. Statistik uji yang digunakan dalam model ini yaitu statistik $\mathrm{t}$ atau uji-t, yaitu membandingkan nilai $\mathrm{t}$ tabel dengan nilai $\mathrm{t}$ statistik. Nilai t pembanding yang digunakan berasal dari nilai t-tabel dengan degree of freedom (df) sebesar 95 dan tingkat kekeliruan 0,1 (10\%) adalah 1,66105. Berikut penjelasannya:

a) Nilai koefisien (original sample) konstruk PE terhadap BIUS memiliki pengaruh positif sebesar 0,197 dan signifikan pada taraf $10 \%$ dibuktikan dengan nilai $t$ statistik $(1,686)$ lebih besar dibandingkan nilai t tabel $(1,661)$. Jadi, dapat disimpulkan bahwa Ha diterima.

b) Nilai koefisien (original sample) konstruk EE terhadap BIUS memiliki pengaruh positif sebesar 0,044 namun berpengaruh tidak signifikan karena nilai t statistik $(0,506)$ lebih kecil dibandingkan nilai t tabel $(1,661)$. Ha ditolak.

c) Nilai koefisien (original sample) konstruk SI terhadap BIUS berpengaruh positif sebesar 0,224, dan berpengaruh signifikan dengan nilai t statistik 2,262 lebih besar dibandingkan nilai t tabel $(1,661)$. Ha diterima.

d) Nilai koefisien (original sample) konstruk FC terhadap BIUS berpengaruh positif sebesar 0,367 , dan berpengaruh signifikan dengan nilai t statistik $(4,766)$ lebih besar dibandingkan nilai t tabel $(1,661)$. Ha diterima.

Proses Adopsi E-Commerce Agribisnis Menggunakan Teori Difusi Inovasi 


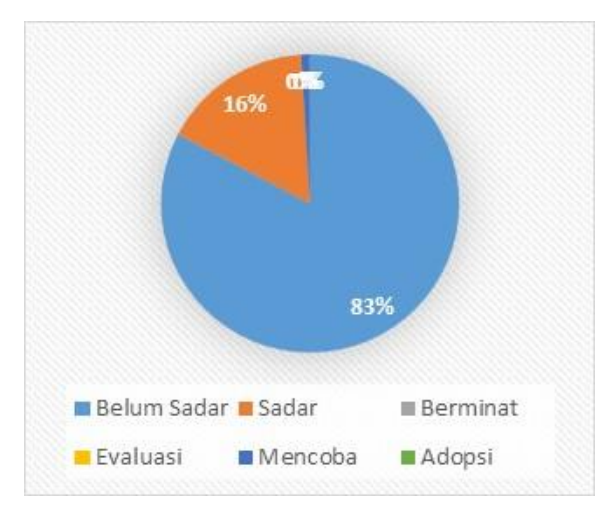

Gambar 7. Tahapan Adopsi Responden

\section{Tahap Awareness (kesadaran)}

Tahap ini ditandai dengan kesadaran ibu rumah tangga akan keberadaan inovasi $e^{-}$ commerce agribisnis dan mengetahui manfaat serta fungsi dari inovasi tersebut. Pada saat melakukan penelitian di lapangan, sebanyak 82 responden belum sadar akan keberadaan inovasi ini. Hal tersebut membuat penulis harus melakukan penambahan pengetahuan kepada ibu rumah tangga agar pandangan mengenai inovasi e-commerce agribisnis semakin terbuka. Setelah pengetahuan dan kesadaran mengenai e-commerce agribisnis dimiliki oleh ibu rumah tangga, hal tersebut akan membawa ibu rumah tangga kepada tahapan selanjutnya yaitu tahap interest (keinginan).

2. Tahap interest (keinginan)

Pada tahap ini ibu rumah tangga mulai membentuk sikap tertarik atau tidak akan inovasi e-commerce agribisnis. Tahapan ini merupakan tahap yang penting dalam menentukan perilaku selanjutnya calon pengguna. Berdasarkan penelitian di lapangan, mayoritas ibu rumah tangga tertarik dan memiliki sikap positif untuk mengetahui lebih lanjut terhadap inovasi e-commerce agribisnis. Ibu rumah tangga sangat tertarik akan kemudahan dan keuntungan yang ditawarkan oleh inovasi tersebut setelah diberi pengetahuan.

3. Tahap evaluation (evaluasi)

Setelah melewati tahap interest (keinginan), tahap selanjutnya dalam proses adopsi inovasi ialah tahap evaluasi. Pada tahap evaluasi, ibu rumah tangga mulai mengevaluasi untuk menerima atau menolak inovasi e-commerce agribisnis. Saat melakukan penelitian di lapangan, mayoritas ibu rumah tangga cenderung bisa bersikap positif dan menunjukkan ketertarikan terhadap inovasi e-commerce agribisnis, namun belum bisa menerima akan inovasi tersebut karena baru mengetahui setelah menulis memberikan informasi. Proses adopsi inovasi e-commerce agribisnis oleh ibu rumah tangga di Kelurahan Sumur Batu, Kecamatan Bantar Gebang, Kota Bekasi belum sampai pada tahap evaluasi.

4. Tahap trial (mencoba)

Ibu rumah tangga di Kelurahan Sumur Batu belum sampai pada tahap trial (mencoba) inovasi e-commerce agribisnis karena belum mengimplementasikan hasil dari tahapan sebelumnya yaitu penerimaan dan belum menggunakan bentuk dari inovasi e-commerce agribisnis. Hanya satu orang ibu rumah tangga dengan latar belakang Pendidikan lulusan diploma, dan tinggal di perumahan pernah mencoba e-commerce tersebut. Pernyataan tentang latar belakang tersebut sejalan dengan pendapat yang dikatakan Rogers dan Schumaker (1971) dan Soekartawi (1988) yang menyatakan bahwa faktor Pendidikan memiliki pengaruh dalam kecepatan pengambilan keputusan dalam proses adopsi teknologi.

5. Tahap adoption (adopsi)

Tahapan terakhir dalam proses adopsi inovasi ialah tahap adopsi. Ibu rumah tangga Kelurahan Sumur Batu belum mencapai tahap ini karena pada tahap adopsi mengharuskan 
adopter sudah bisa memastikan dan memutuskan untuk menggunakan inovasi secara berkelanjutan atau tidak.

\section{KESIMPULAN}

Berdasarkan hasil penelitian dan pembahasan mengenai analisis perilaku penerimaan ibu rumah tangga di Kelurahan Sumur Batu, Kecamatan Bantar Gebang, Kota Bekasi mengenai sistem e-commerce agribisnis. Analisis dilakukan dengan menggunakan model Unified Theory of Acceptance and Use of Technology (UTAUT) untuk mengetahui faktorfaktor yang memengaruhi ibu rumah tangga terhadap penerimaan e-commerce agribisnis, maka dapat disimpulkan bahwa:

1. Tingkat Penerimaan e-commerce agribisnis oleh ibu rumah tangga di Kelurahan Sumur Batu, Kecamatan Bantar Gebang, Kota Bekasi memiliki memiliki tingkat yang rendah karena ibu rumah tangga belum menyadari akan keberadaan sistem tersebut. Namun, setelah diberikan pengetahuan mengenai e-commerce agribisnis, ibu rumah tangga memberikan sikap positif dan menunjukkan ketertarikan.

2. Faktor yang paling memengaruhi tingkat penerimaan e-commerce agribisnis oleh ibu rumah tangga di Kelurahan Sumur Batu ialah kondisi pemfasilitasi sebesar 36,7\% karena ibu rumah tangga sudah memiliki pengetahuan dan sumber daya pendukung yang cukup, sedangkan faktor ekspektansi usaha tidak memiliki pengaruh karena kemudahan dari sistem bukan hal utama yang diperhatikan oleh ibu rumah tangga dalam meningkatkan minat penggunaan.

\section{DAFTAR PUSTAKA}

Admin e marketer. 2016. Retail Ecommerce Sales in Select Countries in Southeast 10 Asia. https://www.emarketer.com/chart/196787/retail-ecommerce-sales-select-countriessoutheast-asia-2016-billions

Arikunto, Suharsimi., (2001), Prosedur Penelitian, Suatu Pendekatan Praktek. Jakarta: Bina Aksara.

Arning, K., \& Ziefle, M., (2007), Understanding Age Differences in PDA Acceptance and Performance. Computers in Human Behaviour.

Azwar, S., (1999), Reliabilitas dan Validitas. Yogyakarta: Sigma Alpha.

Chin., w.w., (1998), The Partial Least Square Approach to Structural Equation Modeling. In Modern Methods for Business Research.

Ghozali, Imam., (2006), Aplikasi Analisis Multivariate dengan Program SPSS (Edisi ke 4). Semarang. Badan Penerbit Universitas Diponegoro.

Hang Liu, Yuming Wang, Kim Xie., (2013), Agricultural E-Commerce Sites Evaluation Research. China (CN). Vol. 4 No. 17 [Special Issue-December 2013]. Shanghai University of Engineering Science.

Noor, Juliansyah., (2014), Metodologi Penelitian. Jakarta: Kencana.

Rogers, E.M. dan Shoemaker, F.F., (1971), Communication of Innovation. London. The Free Press.

Soekartawi., (1988), Prinsip Dasar Manajamen Pemasaran Hasil Pertanian Teori dan Aplikasi. Rajawali Press. Jakarta. 
Sugiyono., (2008), Metode Penelitian Kuantitatif Kualitatif dan R\&D. Bandung Alfabeta.

Sugiyono., (2014), Metode Penelitian Pendidikan Pendekatan Kuantitatif, Kualitatif dan R\&D. Bandung: Alfabeta.

Venkatesh, V., \& Morris, M. G., (2000), Why Don't Men Ever Stop to Ask Directions? Gender, Social Influence, and Their Role in Technology Acceptance and Usage Behaviour. MIS Quarterly: Management Information Systems.

Zapata D.S., Lamio. R.D., Isengildina-Massa. O., Carpio C.E., (2013), Does E-commerce Help Agricultural Markets? (The Case of MarketMaker). China (CN). The Magazine of food, farm, and resource issues. Vol 28 No 24. 